\title{
A licenciosidade possível em Enervadas (1922), de Mme. Chrysanthème
}

\author{
Ana Paula A. dos Santos*
}

\section{Introdução}

Em seu conto "Sob as estrelas" (1940), a escritora carioca Júlia Lopes de Almeida (1862-1934) narra um embate entre os prazeres sexuais e a castidade religiosa sob a forma do envolvimento entre um padre, Júlio, e sua companheira de infância, a cabocla Ianinha. Tendo vivido um romance precoce, os personagens se separam no momento em que Júlio é obrigado a entrar no seminário. Prevendo o abandono no qual ficaria após a separação, Ianinha diz a Júlio que "o amava, que lhe dera sua virgindade, a sua alma, que a vida era aquilo, a liberdade, o beijo, o amor!" (AlmeIDA, 1940, p. 90).

O discurso em prol dos prazeres carnais e da liberdade sexual faz com que a personagem seja malvista na cidade interiorana onde mora: chamam-na de peste e acusam-na de estar associada ao demônio (cf. Almeida, 1940, p. 90). Ainda assim, após anos de separação, quando o padre reencontra a antiga namorada, ela volta a defender o argumento de outrora, e pede a Júlio que abandone o celibato e escolha uma vida de amor "sob as estrelas":

Pecar? Não era pecado! Que seria o mundo, sem a perpetuação do amor! Ianinha arrancava aquilo da sua imaginação caudalosa, lamentando-se por não ter nascido sob outra forma, por não ter a vida libérrima da ave, do inseto ou da flor! (AlmeidA, 1940, p. 96-97).

Evoquei o discurso de Ianinha porque ele aborda o tema sobre o qual pretendo explorar neste trabalho: os problemas relacionados entre o sexo e o gênero feminino na literatura brasileira do século XIX e meados do XX. O lamento da personagem demonstra ao leitor que ela almeja ser um ente que possa ter relações sexuais sem ser julgado e ter a mesma liberdade que uma ave, um inseto, ou mesmo uma flor. Isso porque numa sociedade baseada em valores patriarcais - como é a cidade retratada na narrativa - a atividade sexual feminina é restrita à mulher casada. As solteiras que, como a personagem de Almeida, não respeitam as conven-

Doutoranda em Teoria da Literatura e Literatura Comparada pela Universidade do Estado do Rio de Janeiro (UERJ).E-mail: ana_ads@hotmail.com. 
ções sociais são vistas como imorais, transgressoras. Nesse sentido, as representações ficcionais dessas mulheres parecem ter poucas alternativas para se impor contra essas restrições sexuais. Como afirma Leonardo Mendes (2016, p. 345-346) a masturbação, a melancolia, a loucura e a morte são suas sinas mais frequentes.

A sexualidade feminina estabeleceu-se como uma profícua temática da literatura licenciosa. Foi abordada na ficção pornográfica de Rabelais (cf. DUARTE, 2017, p. 16-17), e largamente explorada pelos escritores naturalistas (cf. Mendes, 2016, p. 344-346). Na literatura brasileira do século XIX e meados do século XX, temas como o celibato forçado às mulheres solteiras e às viúvas são o foco de romances como O homem (1887), de Aluísio Azevedo, A carne (1888), de Júlio Ribeiro, O aborto (1893), de Figueiredo Pimentel, e também de contos como "Noivados trágicos" (1898), de Medeiros e Albuquerque.

Contudo, interessa-me saber de que forma as escritoras do período abordaram tais assuntos. Júlia Lopes de Almeida legou-nos, além de "Sob as estrelas", o conto "Os porcos" (1903), cujo enredo destaca a crueldade da punição conferida a outra personagem que ousa ter relações sexuais fora do casamento, e, também, "A nevrose da cor" (1903), que narra a obsessão fetichista de uma femme fatale pela cor vermelha. Porém, a incursão de Almeida no assunto foi breve. A escritora do período que com mais constância abordou temas relacionados ao sexo e a mulher parece ter sido Mme. Chrysanthème (1870-1948), pseudônimo da carioca Cecília Bandeira de Melo Rebelo de Vasconcelos. Sua produção ficcional tem como topos a vida desregrada, não-convencional, adúltera e sexualmente ativa da mulher moderna brasileira.

Para os fins deste trabalho pretendo me focar na obra de Chrysanthème, mais especificamente, em Enervadas (1922). A preferência por esse romance não é aleatória: a obra é escrita sob a forma de um diário em que a protagonista, Lúcia, decide contar a sua história como forma de se rebelar contra o médico que a diagnosticara como uma espécie de histérica:

Se me tivessem achado esgotada, neurastênica, ${ }^{1}$ com o fígado congesto ou o rim mal colocado, eu choraria, temeria a morte, [...] mas "enervada", título com que ele agraciou todos os meus desequilíbrios de moça de moda e da época, obriga-me a alinhar, de ora em diante, em folhas de papel, tudo o que se passa em mim e comigo, para que ele tenha a certeza depois, de que a medicina é uma ciência de intrujice, de ignorância e de palavras sem alcance e sem sentido (Chrysanthème, 1922, p. 5-6).

\footnotetext{
A neurastenia, considerada um "nervosismo moderno", foi entendida como o resultado de um hiperestímulo e das constantes pressões e sensações produzidas no cotidiano da vida urbana moderna (cf. SINGER, 2001). Bastante comum nas personagens da literatura fin-de-siècle, veremos, ao longo de Enervadas, que também Lúcia é frequentemente arrebatada por fortes sensações, quase sempre consequências dos seus envolvimentos amorosos.
} 
Os "desequilíbrios de moça de moda e da época" citados pela personagem de Chrysanthème têm seu início com um casamento feito por impulso - baseado puramente em atração física - e seguem, ao longo da narrativa, com uma paixão desenfreada por um padre, inúmeros casos de adultério, divórcio e um abuso constante de drogas como a morfina e a cocaína. A abordagem desses temas transgressores aproxima Enervadas da tradição literária de romances licenciosos. Essa tradição possuía popularidade incontestável entre os leitores do Brasil do século XIX e meados do XX, por explorar transgressões sexuais femininas - prostituição, lesbianismo e adultério, entre outros temas - e foi um dos muitos gêneros ficcionais privilegiados por escritores polígrafos como Coelho Netto, Figueiredo Pimentel e Olavo Bilac no trajeto de ascensão de suas carreiras literárias.

No entanto, Mme. Chrysanthème explora a sexualidade feminina de forma consideravelmente mais sutil do que os escritores naturalistas ou pornográficos. Levando em consideração (i) as dificuldades enfrentadas pela mulher para ingressar no meio literário e (ii) o fato de que a filiação à literatura licenciosa era malvista pela recepção crítica da época, minha hipótese é a de que Chrysanthème escreveu uma literatura licenciosa dentro dos parâmetros possíveis para uma escritora: atenuada, porém, sem deixar de ser sensual e erótica, e, principalmente, sem abrir mão de representar a liberdade sexual da mulher sob um ponto de vista feminino.

Ao longo deste trabalho busco investigar as marcas pornográficas que podem ser encontradas em Enervadas, não com o intento de afirmar que a escritora carioca escrevia pornografia de fato, mas, em vez disso, considerar que, tal como outros escritores que lhe eram contemporâneos, Chrysanthème estava a par das convenções dessa literatura e fez uso delas em seus romances como forma de atrair o leitor e de cativar o seu público.

\section{O “donjuanismo feminino" de Mme. Chrysanthème}

É tentador dar prosseguimento imediato à análise do romance de Mme. Chrysanthème. Contudo, para melhor compreender a licenciosidade em Enervadas, julgo necessário apresentar alguns pontos a respeito da obra dessa escritora tão pouco conhecida, e discutir alguns aspectos importantes de sua recepção crítica no meio literário do Brasil do século XIX e XX.

Em trabalhos anteriores apontei para as dificuldades vivenciadas pelas mulheres na tentativa de ingressar no meio literário do Brasil oitocentista, uma vez que o ofício era entendido à época como exclusivamente masculino. Tenho argumentado que parte da responsabilidade pela obliteração das escritoras de nossos registros históricos deve-se à falta de incentivo e a uma recepção crítica hostil às suas obras. Porém, a desaprovação de seus contemporâneos não impediu as escritoras brasileiras. A presença constante de mulheres que escreveram poesias, folhetins e romances e contribuíram em periódicos ao longo do século XIX atesta a persis- 
tência com que elas se impuseram na literatura a despeito da aversão comumente legada pelo meio literário à escrita feminina.

A obra de Mme Chrysanthème é um exemplo dessa persistência: ela publicou mais de quinze romances e inúmeros contos e crônicas em jornais importantes e populares, tais como O Paiz, a Gazeta de notícias, O Cruzeiro e o Correio Paulistano. ${ }^{2}$ A leitura de suas crônicas revela que ela foi uma defensora ferina dos direitos femininos, e, por conta disso, nem sempre foi bem vista pelos seus conterrâneos. Afinal, predominam em sua produção jornalística as discussões a respeito dos problemas vivenciados no dia a dia da mulher, tais como o preconceito no mercado de trabalho e o divórcio.

Além disso, o meio jornalístico teve importância significativa para a escritora. Os periódicos foram o veículo pelo qual seus romances e folhetins foram anunciados e resenhados visando angariar futuros leitores:
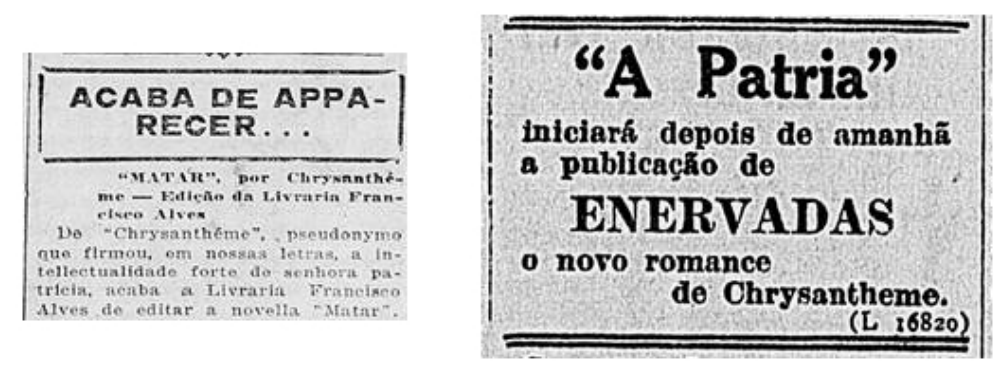

FiguRA 1 - anúncio do romance Matar (1927) na Gazeta de Notícias, 17 de fevereiro de 1927, p. 3; propaganda do início da publicação seriada do romance Enervadas no Correio da manhã, 8 de novembro de 1921, p. 5.

Esses são apenas dois dos muitos anúncios que foram publicados nos jornais ao longo do período literário mais ativo da escritora, entre as primeiras décadas do século XX. Eles não apenas revelam uma estratégia mercadológica que buscava chamar atenção para os seus livros, mas, também, demonstram que Chrysanthème foi uma figura positivamente recebida entre os leitores, popularmente lida e reconhecida à época. A esse respeito, Rosa Gens afirma:

Pela leitura dos títulos dos seus volumes e dos anúncios que os veicularam nos jornais, fica patente o objetivo da autora de atingir um grande número de leitores, através de uma estratégia de sedução pelo apelo ao erótico, ao moderno, ao violento. Muitas vezes, até ao escabroso. As capas de suas edições também cativam o leitor, através da presença de mulheres nuas, cadáveres, expressões faciais enigmáticas (GENS, 2016, p. 1114, 1115).

\footnotetext{
${ }^{2}$ A produção jornalística de Chrysanthème foi inventariada e analisada pela pesquisadora Maria de Lourdes de Melo Pinto. Os resultados dessa pesquisa encontram-se reunidos na tese Memória de autoria feminina nas primeiras décadas do século XX: a emergência da obra periodística de Chrysanthème (2006).
} 
De fato, Chrysanthème conferia títulos chamativos aos seus romances, tais como Gritos femininos (1922), Almas em desordem (1924) e Matar (1927). A estratégia não era desconhecida do meio literário e foi utilizada largamente pela literatura licenciosa. Nas palavras de Alessandra El Far "algumas edições procuravam explicitar seu conteúdo 'picante' através de títulos provocativos capazes de dispensar quaisquer provocações” (2004, p. 191).
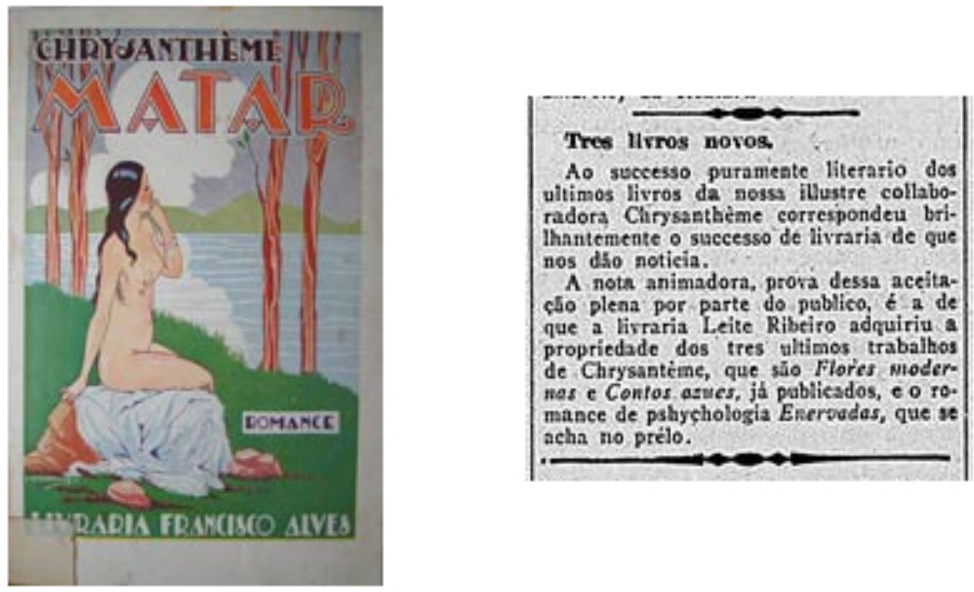

FIgURA 2 - capa do romance Matar, editado pela Livraria Francisco Alves, e anúncio do jornal $O$ Paiz, 3 de abril de 1922, p. 3.

Entre os romances da escritora, talvez Matar seja o mais representativo dessa estratégia: publicado com o subtítulo "romance sensacional e moderníssimo", sua capa traz também a sedutora e convidativa ilustração de uma mulher nua, tal como referido por Rosa Gens. O emprego de tais estratégias mercadológicas na publicação de sua obra, o apelo gráfico e principalmente o conteúdo de seus livros ajudam a pensar na popularidade almejada e adquirida por Chrysanthème à época. O anúncio d'O Paiz parece confirmar essa suposição, pois sugere que seus romances possuíam "aceitação plena por parte do público" e seriam responsáveis pelo êxito da Livraria Leite Ribeiro.

Se, por um lado, entre os leitores, a obra de Mme. Chrysanthème era um "sucesso puramente literário", cujas vendas possivelmente alavancaram a livraria que adquirira seus direitos de publicação, a recepção crítica não encarou a escritora com o mesmo entusiasmo. Em seu estudo, Maria de Lourdes Pinto esclarece que:

Apesar de sua labuta literária e da constante procura pela atualização por viver o seu tempo, os seus contemporâneos, pelo menos os críticos, souberam ser bastante mordazes em seus comentários. Só não sabemos se o preconceito era por ela ser mulher ou por viver da pena ou pelos dois. Não podemos esquecer-nos de que a crítica de então primava pelo biografismo, o que pesava contra nossa escritora pelas escolhas que muitas vezes fazia (PINTO, 2006, p. 127). 
Como muitas outras escritoras de sua época, Chrysanthème recebeu pouca atenção da crítica literária e quase nenhuma menção nos manuais de literatura. Dos poucos críticos que analisaram sua obra é possível notar uma aversão que se deve menos aos aspectos formais de seus romances do que ao conteúdo de sua obra, considerado imoral e impróprio para a leitura. Veja-se por exemplo Agripino Grieco:

Depois de escrever lindas histórias para crianças (...), Mad. Chrysanthème entrou a escrever livros meio escandalizantes. Passou a por venenos borgianos nas compotas de manga de caju. Seus heróis dantes faziam apenas orgias domésticas com chá, à tisana elegante dos ricos; hoje, atiram-se à morfina e à cocaína. Mad. Chrysanthème descreve, agora de preferência o mostruário de homens da Avenida e suas heroínas praticam uma espécie de donjuanismo feminino (GRIECO, 1933, p. 183).

A indignação de Grieco reproduz a tônica de muitas outras críticas feitas aos escritores brasileiros, e, principalmente, às nossas escritoras. Censurava-se abertamente as mulheres que escreviam sobre temas que não fossem a vida doméstica, a jardinagem, a educação infantil, isto é, temas considerados "tipicamente femininos”. No cerne dessa censura encontramos argumentos moralistas e tendenciosos, afinal, Grieco parece defender que não caberia à Chrysanthème retratar em sua ficção um lado tão sombrio do ser humano. Ele revolta-se mais especificamente com o que chama de "donjuanismo feminino", o caráter sedutor, libertino das mulheres que protagonizam as obras da escritora.

Assim como Grieco, Humberto de Campos também teceu comentários bastante agressivos a respeito da obra de Mme. Chrysanthème. Para ele, a "bulhenta senhora" (CAMPOS, 1951, p. 114) estava empreendendo, com a sua ficção, uma espécie de cruzada contra o sexo masculino:

Conhecedora da vida e da sociedade em que respira e se move, a Sra. Chrysanthème poderá fornecer as letras brasileiras excelentes romances de observação. Basta que se proponha a escrever mais sossegadamente, e pondo em cena personagens um pouco mais asseados de língua. O que os outros não veem foi escrito, evidentemente, mais para efeito moral do que literário. Teria conseguido o seu objetivo acendendo nas mulheres o ódio ao homem? Eu não creio. Os homens insistirão em fazer piras de amor, e em perjurar. E as mulheres continuarão a acreditar, e a sofrer (CAmpos, 1951, p. 58).

Embora reconheça algumas qualidades de Chrysanthème, Campos a acusa de produzir as suas obras de forma desassossegada e de criar personagens sem apuro linguístico. Esses parecem ser defeitos menores e até mesmo solucionáveis. O literato condena de forma mais categórica o que identifica como um objetivo moralista, combativo, ou, mais acertadamente, feminista da ficção da escritora. Além de reprovável, essa defesa seria em vão, afinal, Campos acredita que às mulheres 
cabe unicamente acreditar e sofrer pelos homens, uma vez que estes continuarão a faltar com seus juramentos. Essa constante social seria mantida a despeito do retrato moderno, independente e sexualmente ativo de personagens femininas que Chrysanthème apresenta em suas obras.

É evidente, portanto, que por conta de sua preferência por temas polêmicos, considerados impróprios para as mulheres escritoras, e por ter privilegiado um tipo de feminilidade considerada imoral à época, Chrysanthème recebeu uma severa desaprovação da crítica literária. Esse foi um fator crucial para o desaparecimento de seu nome dos nossos registros históricos. Diante de tais fatos, é pertinente analisar Enervadas de modo a garantir à obra uma leitura que reconheça o seu conteúdo licencioso sem os julgamentos morais que a crítica literária contemporânea legou a ela.

\section{Enervada, histérica, prostituta}

Comentei anteriormente que a protagonista de Enervadas é diagnosticada com uma moléstia feminina: para o Dr. Maceu Pedrosa ela é uma "enervada". Lúcia discorda dessa condenação, pois seu problema não aparenta ser uma doença, e sim o que classifica como "eflúvios de uma alma de mulher bem da sua época" (Chrysanthème, 1922, p. 6). Tais eflúvios possuem um caráter claramente sexual, como demonstra a reflexão da personagem:

Será ser "enervada" ter-se vontade de beijar um médico moço e bonito que nos visita na intimidade do nosso quarto, que nos apalpa e nos ausculta com carinho e a quem nós confessamos os nossos gostos, os nossos sonhos, os nossos temperamentos? (CHRYSANTHÈME, 1922, p. 7).

No excerto, Lúcia entende que ao diagnosticá-la como enervada o doutor está implicitamente condenando a sua liberdade sexual, considerada imprópria para uma mulher, especialmente para uma mulher casada. E, se a medicina desaprova a sua libido, a sociedade tampouco seria diferente:

Eu possuo umas parentas velhas que me julgam uma criatura abandonada por Deus e condenada às fogueiras infernais. Quando me encontram na rua (...) elas fecham e sombreiam as velhas e murchas faces (...). Eu rio-me, sempre, nessas ocasiões, mas oculto uma intensa vontade de lhes dizer que eu não sou tão ruim, nem tão pecadora como elas me julgam, segundo a sua estreita visão da virtude (CHRYSANTHÈME, 1922, p. 9-10).

As instituições morais, a família e a religião, são representadas no romance pelas parentas acima citadas. Por meio da reação negativa das velhas senhoras os leitores compreendem que o comportamento de Lúcia é um desvio dos códigos morais da época. Não à toa, ela é considerada uma pessoa ruim, uma pecadora, uma 
mulher sem virtude. A esse respeito, o teórico Leslie Fiedler (1997, p. 67. Tradução minha) comenta que "numa sociedade onde a moralidade tende a ser associada, cada vez mais, à continência sexual, onde 'ser bom' é igual a 'ser casto', [...] há uma demanda natural por 'pureza', no sentido mais físico da palavra”. Nesse sentido, a protagonista de Enervadas não pode ser considerada de forma alguma pura e virtuosa; ao contrário, nessa visão de mundo em que a mulher é julgada pela continência sexual Lúcia é, de fato, uma enervada, uma histérica, não muito diferente de uma prostituta.

Essa personagem arquetípica da literatura pornográfica costuma protagonizar narrativas em que pratica e fala abertamente sobre suas experiências, compartilhando sem pudor o seu conhecimento sobre sexo. Talvez por isso o imaginário do século XIX tenha entendido as personagens ficcionais que se desviavam do modelo de virtude feminina como prostitutas. Afinal, também estas eram mulheres que não restringiam seus desejos sexuais e sabiam como saciá-los conforme as suas vontades. Nessa categoria podemos incluir, por exemplo, a personagem Maricota de $O$ Aborto. Menos interessada em casamento do que em satisfazer sua libido, sua maior audácia é tomar a iniciativa para relacionar-se sexualmente com o primo Mário. Tal atitude foi entendida como um ato transgressor e moralmente impensável para uma jovem solteira, de família honrada. Por isso Maricota foi acusada de possuir um comportamento prostituído (cf. VIEIRA, 2015, p. 96).

Tal como Maricota, a personagem de Chrysanthème demonstra o mesmo desinteresse pelo matrimônio. Seu primeiro envolvimento amoroso é um caso inicialmente despretensioso com Julio, o seu par de dança. Ela sente-se aliviada por ele não lhe propor casamento (cf. CHRYsANTHÈME, 1922, p. 21), afinal, o que atrai a personagem é a compatibilidade que possuem como dançarinos, a volúpia nascida durante os sensuais movimentos do tango, do foxtrot, da mazurca. O relacionamento entre ambos dispensa os usuais idealismos do amor romântico, pois é baseado apenas em atração física: "Julio nunca me disse que me amava, mas me enlaçou com mais força contra ele no dia em que compreendeu que me perturbava" (Chrysanthème, 1922, p. 22-23). Nesse sentido, Lúcia - como a protagonista de O aborto -, não se incomoda em tomar a iniciativa para satisfazer a atração física que sente pelo dançarino: "Fui eu quem lhe ofereceu os lábios que ele aceitou depois de uma leve hesitação... Por isso o meu primeiro beijo, foi frouxo, sem sabor, inexpressivo. Não fiz caso..." (CHRysANTHÈME, 1922, p. 24-25).

Embora nem Lúcia nem Julio estivessem interessados em casamento, o flerte entre ambos pressiona o pai da personagem a firmar um acordo com o dançarino. Diante das pressões sociais os dois cedem. O resultado é fatal para Lúcia: a união sem amor, baseada apenas na volúpia dos passes de dança, será o início sua trajetória como "enervada". Se, jovem e despreparada, Lúcia não é capaz de prever o futuro do casamento para o qual é encaminhada, a personagem logo percebe o erro que cometera: "Nunca li simpatia nem carinho no olhar amarelo [de Julio], mas antes uma repugnância mesclada de receio. Nós tínhamos separado os 
quartos e ele no dele, eu no meu, esperávamos, cada um de seu lado, que o jantar nos reunisse" (CHRYSANTÈme, 1922, p. 48). Ela vê-se isolada e eternamente desamparada, ligada à miserabilidade do seu companheiro que não lhe mostra nem ternura, nem interesse, e só age de forma gentil e zelosa quando dançam juntos (cf. Chrysantème, 1922, p. 50, 51).

A esse respeito, Laura, uma amiga de Lúcia, aponta que esta "casara-se com um dançarino e não com um homem [...]" (CHrysantème, 1922, p. 94). A protagonista de Enervadas torna-se, então, uma "infeliz caçadora de sensações amorosas" (Chrysanthème, 1922, p. 94). Seu malogrado casamento acarreta uma série de casos de adultério que se tornam a base dos relatos do diário de Lúcia, e o principal modo pelo qual Chrysanthème entretém o seu leitor. Para os fins deste trabalho destaco alguns desses romances extraconjugais: o desejo pelo padre Jeronymo dos Reis, a paixão romântica pelo ministro Pedro Monteiro, e o breve affaire com o pintor George Denis.

\section{Os amores adúlteros de Lúcia}

O tema da infidelidade é um dos mais recorrentes na literatura licenciosa: Elisabeth Ladenson argumenta que "os séculos XIX e XX viram uma ênfase cada vez maior em várias formas de comportamento sexual: o adultério, notavelmente, [...] tornou-se o foco obsessivo dos romances realistas, particularmente no decorrer do século XIX" (2016, p. 234. Tradução minha). Apesar de o comentário especificar a literatura licenciosa na França, ele pode facilmente ser aplicado à de língua portuguesa - que, vale ressaltar, possuía à época um diálogo incontestável com a tradição francesa. Se nesta tivemos o célebre Madame Bovary (1856), cuja publicação rendeu graves acusações e um processo judicial contra o seu autor, Gustave Flaubert, naquela, uma situação semelhante condenou O primo Basílio (1878), de Eça de Queirós. O argumento moralista ia de encontro a esses romances, tanto em França quanto em Portugal, mas não impediu que as narrativas de infidelidade feminina tenham se tornado um atrativo para os leitores, que liam as histórias de desejos sexuais moralmente transgressores tal como liam pornografia (cf. MeNDEs, 2016).

Ladenson aponta ainda que, em uma parte considerável da ficção do século XIX e XX, esses "desejos ilícitos podem ser retratados como tendo servido de base para alguns atos, mas estes nunca são efetivamente descritos e nem mesmo são diretamente evocados" (2016, p. 234. Tradução minha). Ainda assim, eles suscitam no leitor as sensações típicas da literatura pornográfica ao evocar um imaginário que envolve sexo e transgressão.

Acredito que esse tenha sido um dos motivos pelo qual Madame Chrysanthème tenha explorado mais minuciosamente os casos extraconjugais de Lúcia ao longo do romance. Sem narrar cenas explícitas de atos sexuais, a escritora investiu no erotismo transgressor de suas paixões, conferindo especial atenção para a sensualidade e a volúpia da protagonista, como torna-se perceptível em suas fantasias 
com o padre Jeronymo, filho de um amigo de seu pai: "A minha imaginação ociosa começou logo a trabalhar e nas minhas noites de insônia ou durante os meus ataques diurnos de hipocondria, eu evocava esse homem moço que envergara por amor as vestes do sacrifício e da solidão" (CHRYSANTHÈME, 1922, p. 57-58).

A paixão profana pelo jovem padre desperta em Lúcia o desejo que o casamento não mais lhe proporcionava e causa uma série de sensações equivalentes à excitação sexual: quenturas íntimas, frêmitos, palpitações e estranhas emoções frequentemente tomam o corpo da personagem nas ocasiões em que ela se encontra sozinha com Jeronymo (cf. Chrysanthème, 1922, p. 58-6o). Apesar de casada, Lúcia transforma-se em uma coquette e não mede esforços para seduzir o padre:

Encostei, como fizera com Julio, o meu braço, alvo e descoberto, à manga negra da sua sotaina. Ele recuou, fitou-me um minuto, mas, diante do meu rosto infantil que tomara uma doce expressão de humildade, sob a qual ele não soube descobrir o lado amoroso, Jeronymo sorriu e elogiou a noite. Eu tinha ímpetos de o morder... (CHRYsANTHÈME, 1922, p. 62).

Só com grande esforço Lúcia consegue conter a malícia de suas ações diante do religioso. Não por acaso, portanto, o empenho da personagem para conquistá-lo é comparado ao plano de vingança arquitetado por Lúcifer contra Deus (cf. CHRYSANTHÈME, 1922, p. 61). O subtexto religioso desse affaire não me parece gratuito: casada, porém, flertando com um membro da Igreja Católica, o desejo de Lúcia por Jeronymo configura-se como uma dupla e excitante transgressão para os leitores. Além disso, esse caso extraconjugal específico parece retomar a profícua tradição da pornografia anticlerical. Ligando o clero, a religião e o sexo, essa vertente da literatura licenciosa especializou-se em "histórias sobre o apetite sexual insaciável de padres e freiras" (Mendes, 2016, p. 358). No entanto, enquanto algumas das obras que melhor representam a pornografia anticlerical - como, por exemplo, Os serões do convento (1850), de M. L. - narram o sexo anticonvencional de forma sugestiva ou explícita, o desejo de Lúcia pelo padre é anunciado, fantasiado, mas não chega a ser consumado. A frustração da personagem é o estopim para o seu segundo caso adúltero com o ministro do Exterior, Pedro Monteiro. Lúcia classifica-o como um romance de paixão (cf. CHRYsANTHÈME, 1922, p. 97).

Tal como no envolvimento com o padre, privilegia-se, na narração do novo caso de adultério de Lúcia, as sensações da protagonista no decorrer do envolvimento amoroso:

Verifico que Pedro Monteiro me interessou extraordinariamente, que eu passei longos momentos a evocá-lo com a sua cabeleira negra que um ou outro fio branco riscava com graça e que, no dia em que ele cravou a sua boca na minha, quase com raiva, eu pensei morrer... de sensação. [...] Trescalavam ardentes perfumes e assemelhavam-se a mulheres pequeninas em mal de amor. Arrastei o meu adorador para o banco que 
uma frondosa mangueira protegida da resplandecente luz e nessa sombra doce, de mãos entrelaçadas, ele me murmurava palavras que me faziam palpitar e a que eu misturava o aroma capitoso que as flores me serviam (CHRYSANTHÈME,1922, p. 90-92).

O erotismo de ambas as cenas advém da narração dos desejos de Lúcia pelo novo amante. Ainda que esse adultério seja de fato perpetrado - diferente do caso com Jeronymo - Chrysanthème não explicita nenhum ato sexual, investe apenas na atração física, na evocação da imagem do ministro, no modo como ela é arrebatada por uma "sensação" ao ser beijada, nas palpitações sentidas por conta do ambiente romântico e das palavras do seu adorador.

Os inúmeros adultérios encaminham o casamento de Lúcia com Julio para o divórcio. A personagem inicia, então, uma vida desregrada repleta de novos envolvimentos amorosos, indisposições e drogas: "a vida boêmia principiara para mim e, como um pássaro tonto, eu me pendurei aos diversos galhos da árvore tormentosa e envenenada que a sombreia" (Chrysanthème, 1922, p. 108). A imagem evocada para descrever esse momento específico da vida de Lúcia é bastante sombria, uma vez que a repreensão da sociedade e dos familiares torna-se ainda mais severa após o divórcio. É nesse obscuro período que a protagonista se envolve brevemente com um pintor de nus femininos, George Denis, um francês descrito como um "louro efebo" (Chrysanthème, 1922, p. 110).

A relação de Lúcia com Denis é mais um ponto em comum entre Enervadas e a literatura pornográfica, pois personagens efebos - tal como as ninfetas - são uma constante no gênero. Esse arquétipo é representado por jovens atraentes, delicados, narcisistas e afeminados (cf. MendEs, 2016, p. 347-348) que são as principais figuras de um tipo específico de relação considerada transgressora porque diz respeito ao envolvimento amoroso de um homem ou mulher mais velha pelo jovem efebo.

Nestes termos, Lúcia torna-se, a um só tempo, a musa e a amante do pintor, e, numa cena voyeurística, é retrata por este último como uma huri, que, na religião islâmica, representa uma jovem de extrema beleza, uma das virgens do paraíso: "Oito dias após essa exposição, George jantava em minha casa e, diante da 'toilette' que me despia, ele se prontificara a fazer o meu retrato em 'houri'" (Chrysanthème, 1922, p. 110).

A sensual relação entre pintor e musa termina logo em seguida por um capricho desta última. Porém, Denis não é o último dos amantes de Lúcia; pelo contrário, a ele se seguem outros envolvimentos amorosos, uma vez que a personagem passa a crer que a sua necessidade de amar muito e sempre seria a única cura possível para os dissabores da vida, para enfrentar a crítica da sociedade em relação ao seu comportamento fora dos padrões (cf. ChrYsAnthème, 1922, p. 64; 109). Ao admitir essa possibilidade, Lúcia dá razão ao doutor que a diagnosticara como "enervada" e assume-se como tal, isto é, como uma mulher moderna, sexualmente ativa, presa 
de diferentes tipos de paixões transgressoras - e, por isso, encarada pelos demais como portadora dessa moléstia tipicamente feminina.

\section{Conclusão}

Muitas das principais narrativas pertencentes à literatura pornográfica constituem-se como histórias das aventuras sexuais de prostitutas, ou, então, exploram a iniciação sexual e/ou os prazeres obtidos por mulheres solteiras ou casadas em seus envolvimentos amorosos. A mulher é, sem dúvida, uma personagem imprescindível dessa literatura e o relato de suas experiências é um entretenimento almejado pelo seu leitor. No entanto, a maior parte dessas narrativas foi indubitavelmente escrita por homens e para homens - embora ambos os sexos tenham apreciado a pornografia ficcional. Por isso, reconhecer algumas características da pornografia na literatura escrita por mulheres me parece um exercício importante para compreender como a perspectiva feminina retratou o mesmo assunto. Dessa forma é possível investigar mais profundamente não apenas a ficção feminina, mas, também, a pornográfica.

Nesse sentido, Enervadas é uma obra ímpar. Conforme demonstrei ao longo da análise da obra, Mme. Chrysanthème parece consciente do que a literatura licenciosa possuía de mais atraente e não poupa o leitor da sensualidade, do erotismo, do escândalo e dos envolvimentos profanos, adúlteros e transgressores de sua protagonista. O diário de Lúcia pode - e deve - ser lido como a narrativa excitante que aborda as vivências de uma mulher moderna, cujos romances reúnem alguns dos principais topoi da literatura licenciosa: a atração física, sem os idealismos do amor romântico, a liberdade sexual feminina, o anticlericalismo e o envolvimento amoroso com efebos.

Embora para os séculos XIX e XX Lúcia possa ser de fato considerada vítima de uma doença dos nervos - uma enervada, histérica, ou neurastênica como tantas outras personagens femininas da época - a obra parece, até certo ponto, argumentar a favor da protagonista, e ressaltar que ela não é exatamente vítima de uma doença, mas sim do desejo por sexo e por amor ao qual a sociedade enxerga como um tabu condenável.

Tenho argumentado que a escrita feminina procurou ressaltar as dificuldades referentes à condição da mulher: a violência física e psicológica sofrida por elas, a opressão e os seus anseios e frustrações diante de uma sociedade que frequentemente se mostra desfavorável. Além de confirmar tal proposição, a obra de Chrysanthème abre o caminho para uma discussão ainda maior, que diz respeito a como as mulheres retrataram, em sua ficção, os problemas femininos relacionados ao sexo. Enervadas comprova que os topoi da literatura pornográfica estavam ao alcance da escrita feminina tanto quanto da masculina. Coube às escritoras como Chrysanthème, que se aventuravam no tema, criar uma literatura licenciosa mais ou menos adequada ao que se esperava de uma ficção feminina. 


\section{Referências}

AlmeIdA, Júlia Lopes de. Sob as estrelas. In: Ânsia eterna. $2^{\text {a }}$ edição (refundida pela autora). Rio de Janeiro: S. A. A Noite, 1940.

Campos, Humberto de. Crítica: primeira série. Rio de Janeiro: W. M. Jackson, 1951.

Chrysanthème. Enervadas. Rio de Janeiro: Leite Ribeiro, 1922.

Correio Da Manhã. "A Pátria”. Rio de Janeiro, 8 de novembro. 1921.

DuArte, Aline Moreira. "Alfredo Gallis, o pornógrafo esquecido". Revista Graphos, João Pessoa, UFPB, vol. 19, n 2, p. 7-20, 2017.

EL FAR, Alessandra. Páginas de sensação - Literatura popular e pornográfica no Rio de Janeiro (1870-1924). São Paulo: Companhia das Letras, 2004.

Fiedler, Leslie A. Love and death in the American novel. Estados Unidos da América: Dalkey Archive Press, 1997.

Gazeta de Notícias. Acaba de aparecer.. "MATAR”, por Chrysanthème - Edição da Livraria Francisco Alves. Rio de Janeiro: 17 de fevereiro, 1927.

Gens, Rosa. "Cecília Vasconcelos e as modernas mulheres: a figuração de Chrysanthème”. In: Encontro AssociaçÃo Brasileira de Literatura Comparada (ABRALIC), 15., 2016. Rio de Janeiro. Anais. Rio de Janeiro: Dialogarts, p. 1112-1119, 2016.

Grieco, Agripino. Evolução da Prosa Brasileira. Rio de Janeiro: Ariel, 1933.

Ladenson, Elisabeth. "Literature and sex". In: Lyons, John D. (ed.) The Cambridge companion to French literature. Cambridge: Cambridge University Press, p. 222240, 2016.

Mendes, Leonardo. "Biblioteca do Solteirão: o livro pornográfico nas conexões Brasil-Europa no final do século XIX”. In: ABREU, Márcia. (ed.). Romances em movimento: A circulação transatlântica dos impressos. Campinas: Ed. Unicamp, 2016.

O PAIz. Três livros novos. Rio de Janeiro: 3 de abril. 1922.

Pinto, Maria de Lourdes de Melo. Memória de autoria feminina nas primeiras décadas do século XX: a emergência da obra periodística de Chrysanthème. Tese de Doutorado. Faculdade de Letras, Universidade Federal do Rio de Janeiro, 2006.

Singer, Ben. "Modernidade, hiperestímulo e o início do sensacionalismo popular". In: Charney, Leo; Schwartz, Vanessa (org). O cinema e a invenção da vida moderna. Tradução de Regina Thompson. São Paulo: Cosac \& Naif, p. 115-148, 2001.

VieIrA, Renata Ferreira. Uma penca de canalhas: Figueiredo Pimentel e o naturalismo no Brasil. Dissertação de Mestrado. Universidade do Estado do Rio de Janeiro, Instituto de Letras, 2015. 
Recebido em 11 de março de 2019.

Aprovado em 6 de maio de 2019.

\section{Resumo/Abstract/Resumen}

\section{A licenciosidade possível em Enervadas (1922), de Mme. Chrysanthème}

\section{Ana Paula A. dos Santos}

No presente trabalho procuro investigar as marcas pornográficas que podem ser encontradas no romance Enervadas (1922), de Mme Chrysanthème, pseudônimo da escritora Cecília Bandeira de Melo Rebelo de Vasconcelos. Meu intento não é o de afirmar que a Chrysanthème escrevia pornografia de fato, mas, em vez disso, considerar que, tal como outros escritores que lhe eram contemporâneos, ela estava a par das convenções dessa literatura e fez uso delas em seus romances como forma de atrair o leitor e de cativar o seu público.

Palavras-chave: narrativa, século XX, pornografia, literatura brasileira, Mme. Chrysanthème.

\section{The possible licentiousness in Enervadas (1922), by Mme. Chrysanthème}

\section{Ana Paula A. dos Santos}

In this paper, I aim to investigate the pornographic elements which can be found in Enervadas (1922), a novel by Mme Chrysanthème, pen name of the writer Cecília Bandeira de Melo Rebelo de Vasconcelos. My intent is not to affirm that Chrysanthème had the intention of writing pornography, but instead to consider that she, along with other contemporary writers, was aware of the conventions of pornographic literature and that she utilized these conventions in her novels as a resource to attract readers and to captivate her readership.

Keywords: narrative, Twentieth century, pornography, Brazilian literature, Mme. Chrysanthème.

\section{La licenciosidad posible en Enervadas (1922), de Mme. Chrysanthème}

\section{Ana Paula A. dos Santos}

En este artículo se busca investigar los elementos pornográficos que se pueden encontrar en Enervadas (1922), una novela de Mme. Chrysanthème, pseudónimo de la escritora Cecília Bandeira de Melo Rebelo de Vasconcelos. Mi intención no es afirmar que Chrysanthème quería escribir pornografía, sino considerar que ella, junto con otros escritores contemporáneos, conocía las convenciones de la literatura pornográfica y que utilizaba dichas convenciones en sus novelas como un recurso para atraer y cautivar a sus lectores.

Palabras clave: narrativa, siglo XX, pornografía, literatura brasileña, Mme. Chrysanthème. 